\title{
Durable remission after treatment with very low doses of imatinib for FIP1L1-PDGFR $\alpha$-positive chronic eosinophilic leukaemia
}

\author{
Grzegorz Helbig $\cdot$ Andrzej Moskwa $\cdot$ Marek Hus $\cdot$ Jarosław Piszcz $\cdot$ \\ Alina Swiderska $\cdot$ Alina Urbanowicz $\cdot$ Małgorzata Całbecka $\cdot$ Ilona Seferyńska $\cdot$ \\ Małgorzata Raźny $\cdot$ Marek Rodzaj • Ewa Żuk $\cdot$ Sławomira Kyrcz-Krzemień
}

Received: 25 September 2010/Accepted: 31 January 2011/Published online: 17 February 2011

(C) The Author(s) 2011. This article is published with open access at Springerlink.com

To the Editor,

The exquisite response to imatinib mesylate in patients with chronic eosinophilic leukaemia (CEL) harbouring the FIP1L1-PDGFR $\alpha(\mathrm{F} / \mathrm{P})$ fusion transcript has been well documented [1-4]. In the up-to-date largest multicentre study, all 27 patients with detectable F/P mutation achieved complete haematological and molecular remission after imatinib therapy and have remained in continuous remission after median of 25 months [2].

The initial daily doses of imatinib ranged from 100 to $400 \mathrm{mg}$ in a majority of published reports, but maintained imatinib doses were not fully established $[2,5]$. It was also demonstrated that imatinib dose reduction or temporary discontinuation was associated with molecular and clinical relapse [6, 7]. Additionally, single cases of imatinibresistant F/P-positive CEL have been reported [8].

G. Helbig $(\bowtie) \cdot$ S. Kyrcz-Krzemień

Departament of Haematology and Bone Marrow

Transplantation, Silesian Medical University, Katowice, Poland e-mail: ghelbig@o2.pl

\section{A. Moskwa}

Department of Haematology,

Provincial Hospital, Gorzow, Poland

\section{Hus}

Department of Haematology,

Medical University, Lublin, Poland

J. Piszcz

Department of Haematology,

Medical University, Białystok, Poland

\section{A. Swiderska}

Department of Haematology,

Provincial Hospital, Zielona Góra, Poland
As the response rate after imatinib is close to $100 \%$, the current issue is (1) to establish a minimal effective imatinib dose needed to remission maintenance and (2) to evaluate the duration of imatinib response.

Recently, we reported on high efficacy of weekly imatinib schedule in $13 \mathrm{~F} / \mathrm{P}$-positive CEL patients. Imatinib at weekly dosage seemed to be sufficient to maintain haematological and molecular remission with a median of 21 months of follow-up in this studied subgroup [9].

Herein, we present long-term results of F/P-positive CEL after imatinib. The data were collected from ten centres in Poland. All patients gave written informed consent. Twenty male and two female patients at median age of 52 years (range 22-80 years) were included in this partially retrospective study. Organ involvement was demonstrated in $91 \%$ of patients, and splenomegaly was the most common clinical manifestation. At diagnosis, $23 \%$ of patients were asymptomatic. Median blood

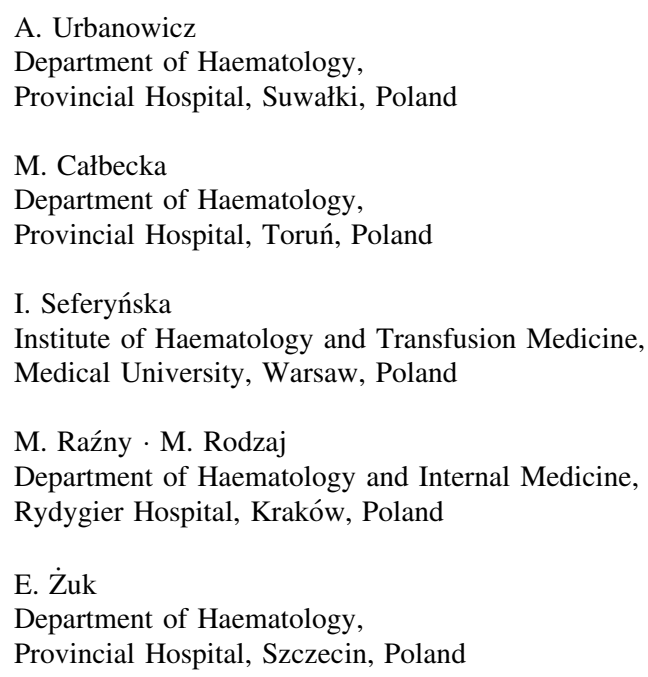


eosinophilia and median bone marrow eosinophil infiltration were $12 \times 10 \%$ (range $2.5-40$ ) and $39.5 \%$ (range 7.0-80), respectively. The starting, de-escalated and maintained imatinib doses were left to the physician's discretion. The initial imatinib doses were as follows: $100 \mathrm{mg} /$ day $(n=18), 400 \mathrm{mg} /$ day $(n=3)$ and $300 \mathrm{mg} /$ day $(n=1)$. All treated patients achieved haematological remission after median of 13 days (range 3-90). Complete molecular remission by nested RT-PCR was confirmed after median of 10 months (range 3-24). They became free of symptoms. The maintained imatinib doses were following: $100 \mathrm{mg}$ per week $(n=11), 200 \mathrm{mg}$ per week $(n=2), 400 \mathrm{mg}$ per week $(n=1), 100 \mathrm{mg}$ twice a week $(n=2), 100 \mathrm{mg}$ thrice a week $(n=2)$ and $100 \mathrm{mg}$ a day $(n=4)$. Imatinib doses and duration of treatment were shown in Table 1. All studied patients remained in complete haematological and molecular remission after median follow-up of 41 months (range 11-71). Median time at maintained imatinib doses was 27 months (range 2-61). Imatinib plasma levels were measured using high-performance liquid chromatography-tandem mass spectrometry method [10]. Blood samples were taken $24 \mathrm{~h}$ after the last imatinib intake from eleven patients: from 9 patients on $100 \mathrm{mg}$ weekly imatinib and from 2 on imatinib at $200 \mathrm{mg}$ a week. Imatinib plasma levels appeared to be extremely low and ranged between 44 and $164 \mathrm{ng} / \mathrm{ml}$ and 103-203 ng/ml, respectively, for both analysed groups. Of note is that $\mathrm{F} / \mathrm{P}$ negativity was confirmed at the same time points by nested RT-PCR.

With this large series of F/P-positive CEL patients, we can confirm that imatinib may induce durable remission with the maximum follow-up of 71 months until last contact. Most recently, Rondoni et al. [11] presented the follow-up results of 33 F/P-positive CEL patients on imatinib with a continuous remission after median of 51 months (range 30-92). In contrary to our report, the maintained imatinib doses were $100 \mathrm{mg}$ a day. It is noteworthy that 18 patients from our study group received imatinib at total maintained doses of $400 \mathrm{mg}$ a week or less. We have proved that treatment with such low imatinib doses may maintain molecular remission despite low imatinib plasma levels. Nevertheless, the longer follow-up is needed to confirm our encouraging results.

Table 1 Imatinib doses and duration of therapy in F/P-positive CEL patients

\begin{tabular}{|c|c|c|c|c|c|c|}
\hline Patients & $\begin{array}{l}\text { Starting imatinib } \\
\text { dose (mg/day) }\end{array}$ & $\begin{array}{l}\text { First de-escalated } \\
\text { imatinib dose }(\mathrm{mg})\end{array}$ & $\begin{array}{l}\text { Maintained } \\
\text { imatinib dose } \\
(\mathrm{mg})\end{array}$ & $\begin{array}{l}\text { Plasma imatinib } \\
\text { level at maintained } \\
\text { imatinib dose }(\mathrm{ng} / \mathrm{ml})\end{array}$ & $\begin{array}{l}\text { Months on } \\
\text { maintained } \\
\text { imatinib dose }\end{array}$ & $\begin{array}{l}\text { Total time } \\
\text { on imatinib } \\
\text { (months) }\end{array}$ \\
\hline Patient 1 & 100 & 200 per week & 100 per week & 46 & 54 & 67 \\
\hline Patient 2 & 100 & 200 per week & 100 per week & 47 & 61 & 66 \\
\hline Patient 3 & 400 & 400 per week & 100 per week & 44 & 3 & 12 \\
\hline Patient 4 & 100 & 100 BIW & 100 per week & 125 & 18 & 54 \\
\hline Patient 5 & 100 & 100 per week & 100 per week & 24 & 34 & 37 \\
\hline Patient 6 & 100 & 100 per week & 100 per week & 67 & 31 & 40 \\
\hline Patient 7 & 100 & 100 per week & 100 per week & 99 & 29 & 30 \\
\hline Patient 8 & 100 & 100 per week & 100 per week & 164 & 56 & 58 \\
\hline Patient 9 & 100 & 100 BIW & 100 per week & 123 & 8 & 17 \\
\hline Patient 10 & 100 & 100 per week & 100 per week & ND & 15 & 51 \\
\hline Patient 11 & 100 & 100 per week & 100 per week & ND & 16 & 19 \\
\hline Patient 12 & 400 & 100 daily & 200 per week & ND & 41 & 63 \\
\hline Patient 13 & 400 & 100 daily & 200 per week & ND & 43 & 45 \\
\hline Patient 14 & 100 & 100 BIW & 100 BIW & 103 & 27 & 28 \\
\hline Patient 15 & 100 & 100 BIW & 100 BIW & 203 & 4 & 14 \\
\hline Patient 16 & 100 & 100 TIW & 100 TIW & ND & 16 & 64 \\
\hline Patient 17 & 100 & 100 TIW & 100 TIW & ND & 11 & 71 \\
\hline Patient 18 & 100 & 100 BIW & 400 per week & ND & 2 & 39 \\
\hline Patient 19 & 100 & NA & 100 daily & ND & NA & 50 \\
\hline Patient 20 & 100 & NA & 100 daily & ND & NA & 37 \\
\hline Patient 21 & 100 & NA & 100 daily & ND & NA & 11 \\
\hline Patient 22 & 300 & 100 daily & 100 daily & ND & 40 & 41 \\
\hline
\end{tabular}

$B I W$ twice a week, $T I W$ thrice a week, $N D$ not done, $N A$ not applicable 
Open Access This article is distributed under the terms of the Creative Commons Attribution Noncommercial License which permits any noncommercial use, distribution, and reproduction in any medium, provided the original author(s) and source are credited.

\section{References}

1. Cools J, De Angelo DJ, Gotlib J, Stover EH, Legare RD, Cortes J et al (2003) A tyrosine kinase created by fusion of the PDGFRA and FIP1L1 genes as a therapeutic target of imatinib in idiopathic hypereosinophilic syndrome. N Engl J Med 348:1201-1214

2. Baccarani M, Cilloni D, Rondoni M, Ottaviani E, Messa F, Merante S et al (2007) The efficacy of imatinib mesylate in patients with FIP1L1-PDGFR $\alpha$ positive hypereosinophilic syndrome. Results of a multicenter prospective study. Haematologica 92:1173-1179

3. Helbig G, Stella-Holowiecka B, Grosicki S, Bober G, Krawczyk M, Wojnar J et al (2006) The results of imatinib therapy for patients with primary eosinophilic disorders. Eur J Haematol 76:535-536

4. Vandenberghe P, Wlodarska I, Michaux L, Zachee P, Boogaerts M, Vanstraelen D et al (2004) Clinical and molecular features of FIP1L1-PDGFRA (+) chronic eosinophilic leukemia. Leukemia 18:734-742

5. Metzgeroth G, Walz C, Erben P, Popp H, Schmitt-Graeff A, Haferlach C et al (2008) Safety and efficacy of imatinib in chronic eosinophilic leukaemia and hypereosinophilic syndromea phase-II study. Brit J Haematol 143:707-715
6. Klion AD, Robyn J, Maric I, Fu W, Schmid L, Lemery S et al (2007) Relapse following discontinuation of imatinib mesylate therapy for FIP1L1/PDGFRA-positive chronic eosinophilic leukemia: implications for optimal dosing. Blood 110:3552-3556

7. Jovanovic J, Score J, Waghorn K, Cilloni D, Gottardi E, Metzgeroth G et al (2007) Low-dose imatinib mesylate leads to rapid induction of major molecular response and achievement of complete molecular remission in FIP1L1-PDGFRA positive chronic eosinophilic leukemia. Blood 109:4635-4641

8. Lierman E, Michaux L, Beullens E, Pierre P, Marynen P, Cools J et al (2009) FIP1L1-PDGFR $\alpha$ D842 V, a novel panresistant mutant, emerging after treatment of FIP1L1-PDGF T674I eosinophilic leukaemia with single agent sorafenib. Leukemia 23:845-851

9. Helbig G, Moskwa A, Świderska A, Urbanowicz A, Całbecka M, Gajkowska J et al (2009) Weekly imatinib dosage for chronic eosinophilic leukaemia expressing FIP1L1-PDGFRA fusion transcript: ectended follow-up. Brit J Haematol 145:132-134

10. Titier K, Picard S, Ducint D, Teilhet E, Moore N, Berthaud P et al (2005) Quantification of imatinib in human plasma by high-performance liquid chromatography-tandem mass spectrometry. Ther Drug Monit 27:634-640

11. Rondoni M, Ottaviani E, Cilloni D, Piccaluga P, Paolini S, Iacobucci I et al (2009) Chronic eosinophilic leukemia with FIP1L1-PDGFRA rearrangement: the response to imatinib is durable. A report of 33 patients with a follow-up of 30 to 92 months. Blood 114:22 (abstract 3894) 